\title{
A New Pathovar, Pseudomonas syringae pv. alisalensis pv. nov., Proposed for the Causal Agent of Bacterial Blight of Broccoli and Broccoli Raab
}

\author{
N. A. Cintas, USDA, ARS, PWA, 1636 E. Alisal Ave., Salinas, CA 93905; S. T. Koike, University of California, \\ Cooperative Extension, Salinas 93905; and C. T. Bull, USDA, ARS, PWA, 1636 E. Alisal Ave., Salinas, CA 93905
}

\begin{abstract}
Cintas, N. A., Koike, S. T., and Bull, C. T. 2002. A new pathovar, Pseudomonas syringae pv. alisalensis pv. nov., proposed for the causal agent of bacterial blight of broccoli and broccoli raab. Plant Dis 86:992-998.

The etiology of three foliar bacterial diseases of crucifers and the relationships between their causal agents were evaluated. Data from LOPAT, carbon utilization tests, and fatty acid analysis indicated that bacterial blights of broccoli and broccoli raab, and leaf spot of broccolini, were caused by strains of Pseudomonas syringae. Data from phage sensitivity, ice nucleation, single carbon source utilization, Polymerase chain reaction using BOXA1R primer (BOX-PCR), and host range analyses were identical for the pathogen causing leaf spot of broccolini and P. syringae pv. maculicola. The broccoli raab and broccoli pathogens infected broccoli raab, all crucifers tested, tomato, and three monocots (California brome, oat, and common timothy). None of the other pathogens tested (P. syringae pv. maculicola, P. syringae pv.tomato, or P. syringae pv. coronafaciens) caused disease on broccoli raab or on both crucifers and monocots. Data from phage sensitivity, ice nucleation, single carbon source utilization, BOX-PCR, and host range analyses were identical for the pathogens from broccoli raab and broccoli, but were different from other pathovars tested, and supported the hypothesis that a new pathovar of $P$. syringae pv. alisalensis pv. nov. caused a leaf blight on broccoli and broccoli raab.
\end{abstract}

Additional keywords: BOX-PCR, coronatine production, phage sensitivity

Broccoli (Brassica olearacea var. botrytis) is a valuable U.S. commodity both nutritionally and economically. It is an excellent source of vitamin $\mathrm{C}$ and provides dietary fiber, protein, iron, calcium, and vitamin A. Broccoli also contains anticancer components (37). The financial benefit of broccoli to the U.S. agricultural industry is significant. The value of the 1999 U.S. broccoli crop was over $\$ 493$ million (1). Approximately $95 \%$ of U.S. broccoli production occurs in California, with Monterey County in the Central Coast Region, producing $50 \%$ of the state's acreage. Monterey County is the leading broccoli producing county in the country (25). Broccoli production in Monterey County in 1999 was worth over \$359 million (23).

Broccoli raab (Brassica rapa subsp. rapa), also known as rappini, has become an important crucifer grown in coastal California for east coast markets (worth

Corresponding author: C. T. Bull

E-mail: cbull@pw.ars.usda.gov

* The $\boldsymbol{e}$-Xtra logo stands for "electronic extra" and indicates the HTML abstract available on-line contains supplemental material not included in the print edition.

Accepted for publication 9 May 2002.

Publication no. D-2002-0628-01R

This article is in the public domain and not copyrightable. It may be freely reprinted with customary crediting of the source. The American Phytopathological Society, 2002. over \$11 million; 23). This leafy vegetable has a flavor between broccoli and mustard greens and is widely grown in Europe (11). Broccolini (Brassica oleracea var. botrytis $\times$ Brassica alboglabra), is another novel crucifer grown in Monterey County. This gourmet broccoli is a cross between broccoli and chinese kale (gai lan). Acreage and demand for this crop are expected to increase over the next few years as consumers become more familiar with it.

Since 1995 , leaf lesions caused by bacteria have begun to appear on all three of these hosts. Bacterial leaf spot of cauliflower, caused by $P$. syringae pv. maculicola, was initially documented in 1911 (29). Although this pathogen is now known to infect many crucifers $(3,42)$, the symptoms on broccoli raab and broccoli are not similar to those caused by $P$. syringae pv. maculicola. Bacterial blight of broccoli raab was the first crucifer blight described in the Salinas Valley of California (21). Initial symptoms consist of small watersoaked flecks on the lower foliage. These flecks expand and become surrounded by bright yellow borders, which eventually may coalesce and result in large necrotic areas. Later, a similar bacterial blight of broccoli emerged (20). Most recently, a bacterial leaf spot of broccolini developed on transplants (5). Although initial characterization of these pathogens suggests that they are related pathovars of $P$. syringae, specific characterization was incomplete (6).

In the Salinas Valley, many fields are planted with two crops of crucifers in 1 year. The second crucifer crop can become infected when planted in residue of a previous crop that had one of the bacterial blights. The broccoli raab bacterial blight pathogen caused disease in a second planting of broccoli raab up to 4 months after incorporating the initial infected crop (7). Because the pathogens of broccoli, broccoli raab, and broccolini have not been completely characterized, it is not known if they have the same or similar host ranges. We are, therefore, unable to predict if the pathogen from one crop has the potential to infect a second planting of a different host. Having a better understanding of the host range of these pathogens would be useful to make crop rotation recommendations for second plantings. Our goal was to characterize the pathogens to aid in making these management choices. The specific objectives of this work were: (i) to determine if these three new bacterial diseases are caused by the same pathogen; (ii) to clarify host ranges of these three bacterial pathogens; and (iii) to clarify the taxonomy of these pathogens.

\section{MATERIALS AND METHODS}

Microorganisms and media. The bacteria used in these studies are listed in Table 1 . For all experiments, $P$. syringae pv. coronafaciens, $P$. syringae pv. syringae, $P$. syringae pv. maculicola, and $P$. syringae pv. tomato were used as controls. The bacteria were stored at $-80^{\circ} \mathrm{C}$ in a solution of $50 \%$ glycerol and 50\% nutrient broth (NB; Difco Laboratories, Detroit, MI) and routinely cultured on King's medium B agar (KMB; 16). All chemicals were purchased from Sigma Chemical Company (St. Louis, MO) unless otherwise indicated.

Isolation of the causal agent. Symptomatic leaves were surface-sterilized with $(0.525 \%)$ sodium hypochlorite for $1 \mathrm{~min}$ followed by rinsing in sterile distilled water three times. Small $(3 \times 3 \mathrm{~mm})$ sections of tissue were aseptically excised from leaf spot margins and macerated in $40 \mu \mathrm{l}$ of sterile distilled water. The resulting suspensions or a dilution were streaked on sucrose peptone agar (4) and incubated at 24 to $26^{\circ} \mathrm{C}$. After 3 to 5 days, single colonies were purified and stored.

Isolations of fungi from diseased tissue were attempted because fungal diseases cause lesions on the leaves of crucifers in the Salinas Valley $(18,22)$. Small leaf sections were aseptically removed and placed on acidified potato dextrose agar $(2 \mathrm{ml}$ of lactic acid per liter). Plates were incubated 
under lights at $24^{\circ} \mathrm{C}$ and examined after 3 to 7 days for fungal growth.

Pathogenicity tests. The causal agents of the new diseases and strains of the control pathovars were tested on plants from the host range of $P$. syringae pv. tomato, $P$. syringae pv. maculicola, $P$. syringae pv. coronafaciens and the hosts of the new diseases. Hosts tested included: broccoli (cv. Greenbelt), cauliflower (Brassica oleracea subsp. botrytis cv. White Rock), broccoli raab (cv. Spring), broccolini (cv. Aspabrock), California brome (Bromus carinatus), corn (Zea mays cvs. Kandy Korn and Silver Queen), oat (Avena sativa cv. Montezuma), rye (Secale cereale cv. Merced), common timothy (Phleum pratense), and tomato (Lycopersicon esculentum cv. Early Girl).

To test pathogenicity, NB was inoculated with individual strains and cultures were shaken at $200 \mathrm{rpm}$ for $24 \mathrm{~h}$. Cultures were centrifuged at $7,000 \mathrm{rpm}$ for $10 \mathrm{~min}$, the broth decanted, and the bacterial pellet resuspended in sterile, distilled $\mathrm{H}_{2} \mathrm{O}$. The resulting bacterial suspensions were adjusted to an optical density of 0.10 at 600 $\mathrm{nm}$ with a spectrophotometer (Shimadzu UV-1601, Kyoto, Japan). This concentration corresponded to approximately $1 \times 10^{7}$ $\mathrm{CFU} / \mathrm{ml}$ as determined by dilution plating. Tween $20(0.05 \%)$ was added to the suspensions, and each suspension was sprayed until runoff using a hand mister. After inoculation, plants were placed in a humid chamber for $48 \mathrm{~h}$, then maintained in a greenhouse at 20 to $25^{\circ} \mathrm{C}$ and evaluated for symptoms after 14 days. For negative controls, plants were treated with sterile, distilled $\mathrm{H}_{2} \mathrm{O}$ plus Tween $20(0.05 \%)$. An experimental unit was six plants in a sixpack container. Each treatment was replicated three times for each host. This experiment was conducted twice, once with plants produced and incubated at the USDA/ARS greenhouse and once at the University of California Cooperative Extension (UCCE) facility. For tests evaluating reactions on tomato, the experiments were conducted four times.

Characterization of pathogens. From each host, three to five strains were tested for morphological, biochemical, and physiological characteristics. When possible, the strains came from separate disease incidences.

Morphology was determined by examining strains grown on mannitol glutamate yeast extract agar plates (MGY; 15). The potassium hydroxide solubility test $(\mathrm{KOH}$ test) to determine gram character and levan formation, oxidase test, potato soft rot, arginine dihydrolase, tobacco hypersensitivity (LOPAT) test were conducted as described previously (34).

For fatty acid analyses, strains were cultured on tryptic soy broth agar (30 g tryptic soy broth, $15 \mathrm{~g}$ agar, 1 liter $\mathrm{H}_{2} \mathrm{O}$; Difco Laboratories, Detroit, MI) at $28^{\circ} \mathrm{C}$ for 24 $\mathrm{h}$, then extracted for fatty acid methyl es- ters using a standard method (30). Fatty acids were analyzed with the Sherlock Microbial Identification System Version 2.11 (MIDI Inc., Newark, DE) that used an automated GC 6890 Hewlett-Packard gas chromatograph fitted with a $25 \times 0.2 \mathrm{~mm}$ phenyl methyl silicone-fused silica capillary column, an HP 7673 automatic sampler, and HP Chem Station Software (30). The analyses included assessing the degree of similarity of fatty acid composition. Analyses were conducted three times for each strain. Strains were also compared three times by their carbon source utilization profiles on Biolog GN microplates (Biolog, Inc., Hayward, CA).

Carbon utilization. Because the use of four carbon sources, erythritol, trigonelline, ascorbic acid, and D-tartrate can distinguish $P$. syringae pv. coronafaciens, $P$. syringae pv. syringae, and $P$. syringae pv. maculicola, the ability of the uncharacterized strains to use these carbon sources was tested under more rigorous conditions. Standard mineral base agar (SMB; $\mathrm{Na}_{2} \mathrm{HPO}_{4} \cdot \mathrm{H}_{2} \mathrm{O}, 4.5 \mathrm{~g} ; \mathrm{KH}_{2} \mathrm{PO}_{4}, 4.5 \mathrm{~g}$; $\mathrm{NH}_{4} \mathrm{Cl}, 1.0 \mathrm{~g} ; \mathrm{MgSO}_{4} \cdot 7 \mathrm{H}_{2} \mathrm{O}, 0.5 \mathrm{~g} ; 5 \%$ ferric ammonium citrate, $1 \mathrm{ml} ; 0.5 \%$ $\mathrm{CaCl}_{2}$ solution, $1.0 \mathrm{ml}$; agar, $16 \mathrm{~g} ; \mathrm{H}_{2} \mathrm{O}, 1$ liter; 10) was used in these experiments. After washing, all glassware was rinsed six times with distilled water. Filter-sterilized active carbon radical $(0.3 \%)$ was added to molten agar after autoclaving. Bacteria were initially cultured on SMB agar with $0.3 \%$ glucose as the sole carbon source before transferring single colonies to the agar with the test carbon sources. Negative and positive controls were among the eight strains present on each plate. Plates were incubated at $27^{\circ} \mathrm{C}$ and results were recorded after 3, 7, and 14 days. Three or four replications were made for each organism and the experiment was conducted three times.

Isolation of phage and test of pathogen sensitivity. A bacteriophage was recovered from standing water in a commercial broccoli raab field in the Salinas Valley in 1998. Enrichment flasks were prepared by adding $50 \mathrm{ml}$ of field water to $2 \mathrm{~g}$ of $\mathrm{CaCO}_{3}$ and $3 \mathrm{ml}$ of overnight $\mathrm{NB}$ cultures of the broccoli raab pathogen. The flasks were incubated at $27^{\circ} \mathrm{C}$ overnight. Standard methods were used to recover and isolate phage as well as determine sensitivity of strains to the isolated phage (17). A routine test dilution giving confluent lysis of the propagating strain was calculated from a prepared phage stock. A 300- $\mu$ l aliquot of an overnight bacterial culture was added to $10 \mathrm{ml}$ of melted soft agar. The suspension was poured over nutrient agar (Difco Laboratories) in a $100 \times 15$ $\mathrm{mm}$ plate. Ten $\mu \mathrm{l}$ drops of $1 \times$ and $10 \times$ concentrations of the routine test dilution were placed on the solidified soft agar plates. The plates were incubated at $27^{\circ} \mathrm{C}$ for $48 \mathrm{~h}$ before recording lysis.

Ice nucleation. Ice nucleating ability was tested as previously described (10). Cultures grown for 4 days at $21^{\circ} \mathrm{C}$ on glucose yeast extract peptone agar (glucose, 5 $\mathrm{g}$; yeast extract, $5 \mathrm{~g}$; peptone, $5 \mathrm{~g}$; agar $5 \mathrm{~g}$; $\mathrm{H}_{2} \mathrm{O}, 1$ liter) were tested for their ability to nucleate ice at $-4^{\circ} \mathrm{C}$. Cells were removed from the plates and suspended in $5 \mathrm{ml}$ of water. Suspensions $\left(>1 \times 10^{9} \mathrm{CFU} / \mathrm{ml}\right)$

Table 1. Bacterial strains used in this study

\begin{tabular}{|c|c|c|}
\hline Strain & Original host & Source \\
\hline \multicolumn{3}{|c|}{ Pseudomonas syringae pv. alisalensis } \\
\hline BS $91^{z}$ & $\begin{array}{l}\text { Brassica rapa subsp. rapa (broccoli raab) ATCC - } \\
\text { accession BAA - } 566\end{array}$ & This study \\
\hline BS92 & B. rapa subsp. rapa (broccoli raab) & This study \\
\hline 1097-11 & B. rapa subsp. rapa (broccoli raab) & Koike (28) \\
\hline BS228 & B. rapa subsp. rapa (broccoli raab) & This study \\
\hline BS130 & B. oleracea var. botrytis (broccoli) & This study \\
\hline BS132 & B. oleracea var. botrytis (broccoli) & This study \\
\hline BS136 & B. oleracea var. botrytis (broccoli) & This study \\
\hline \multicolumn{3}{|c|}{ P. syringae pv. maculicola } \\
\hline $0649-18$ & B. oleracea var. botrytis (cauliflower) & H. Bouzar \\
\hline 0788-18 & B. oleracea var. botrytis (cauliflower) & Koike (28) \\
\hline BS224 & B. oleracea var. botrytis (cauliflower) & Koike (28) \\
\hline BS220 & B. oleracea var. botrytis $\times$ B. alboglabra (broccolini) & H. Bouzar \\
\hline BS221 & B. oleracea var. botrytis $\times$ B. alboglabra (broccolini) & H. Bouzar \\
\hline BS235 & B. oleracea var. botrytis $\times$ B. alboglabra (broccolini) & This study \\
\hline BS236 & B. oleracea var. botrytis $\times$ B. alboglabra (broccolini) & This study \\
\hline BS244 & B. oleracea var. botrytis $\times$ B. alboglabra (broccolini) & This study \\
\hline \multicolumn{3}{|c|}{ P. syringae pv. tomato } \\
\hline $0482-1$ & Lycopersicon esculentum (tomato) & Koike (28) \\
\hline 0183-4 & L. esculentum (tomato) & Koike (28) \\
\hline $0683-23$ & L. esculentum (tomato) & Koike (28) \\
\hline \multicolumn{3}{|c|}{$P$. syringae pv. coronafaciens } \\
\hline NCPPB $600^{\mathrm{z}}$ & Avena sativa (oat) & Koike (28) \\
\hline 345 & Secale cereale (rye) & Cupples (8) \\
\hline ICMP 3114 & A. sativa (oat) & Koike (28) \\
\hline \multicolumn{3}{|c|}{ P. syringae pv. syringae } \\
\hline B301Dr & Pyrus communis (pear) & Xu et al. (41) \\
\hline
\end{tabular}

$\mathrm{z}$ Type strain. 
were held on ice until tested. After adjusting an ice-ethanol water bath to $-4^{\circ} \mathrm{C}$, the bacterial suspensions were immersed in the bath for $5 \mathrm{~min}$. Samples that froze were considered ice nucleation positive. This experiment was conducted twice.

Characterization of coronatine production genes by Southern hybridization. DNA used as probes in Southern hybridization experiments was isolated using Quiagen Tip 100 (Diagen $\mathrm{GmbH}$, Hilden, Germany). Genomic DNA was isolated using CTAB as described in published methods $(2,33)$. Restriction endonucleases were used as recommended by the supplier (GIBCO-BRL Life Technologies, Gaithersburg, MD or Boehinger Mannheim, Indianapolis, IN). DNA was separated by gel electrophoresis at $50 \mathrm{~V}$ for 3 to $12 \mathrm{~h}$ in $0.7 \%$ agarose gels (SeaKem LE; FMC BioProducts, Rockland, ME).

Southern hybridizations were performed on Hybond $\mathrm{N}$ membranes (Amersham, Arlington Heights, IL) using DNA probes that were random-prime labeled with digoxigenin-11-dUTP. Labeling, hybridization, and detection were conducted according to manufacturer's recommendations (Boehinger Manheim). The probe was the coronatine production genes present on pTPR1 cloned from $P$. syringae pv. tomato DC3000 (8). Fragments used as probes were purified from low melting point agarose gels (SeaKem GTG; FMC BioProducts). Adsorption and elution to glass milk was used to remove solutes as described in the manufacturer's recommendations (Geneclean Kit; Bio 101 Inc., Vista, CA). Labeled probes were used at 0.25 $\mu \mathrm{g} / \mathrm{ml}$. DNA to be probed was transferred from agarose gels to nylon membranes by standard methods (33). Hybridization conditions were low stringency (44 to $55^{\circ} \mathrm{C}$ and $\left.0.2 \times \mathrm{SSC}\right)(33)$.
Genotypic characterization using repPCR. The polymerase chain reaction of repetitive bacterial sequences, (rep-PCR), was used to determine the relationship between P. syringae strains causing bacterial blights on broccoli raab, broccoli, and broccolini. PCR amplification of repetitive sequences was accomplished with the BOXA1R primer (5'-CTA-CGG-CAAGGC-GAC-GCT-GAC-G-3'), synthesized by Operon Technologies, Inc. (Alameda, $\mathrm{CA}$ ), that is designed to prime DNA synthesis from the BOXA subunit of the BOX element $(31,38)$. The PCR was carried out according to published methods for BOXPCR using purified genomic DNA (33). DNA samples were prepared by large-scale chromosomal DNA isolations (2). The PCR was carried out in an MJ Research DNAEngine thermo-cycler with a heated lid in the 'block' mode (MJ Research, Watertown, MA) with the use of Taq polymerase (Perkin Elmer, Foster City, CA). Amplified DNA fragments were examined by agarose gel electrophoresis in $1.5 \%$ agarose gels in $0.5 \times$ Tris acetate EDTA buffer, TAE (31). Gels were stained with ethidium bromide and DNA was photographed on a UV transilluminator with Polaroid type 55 film. Fingerprints generated from different strains were compared visually.

\section{RESULTS}

Isolation of the causal agent. No fungi were isolated from broccoli raab, broccoli, and broccolini lesions. Large numbers of fluorescent pseudomonads were consistently isolated from these lesions on blighted broccoli, broccoli raab, and broccolini plants. Isolated suspect bacteria were used to inoculate suspect host plants. Disease resulted, bacteria were reisolated, and Koch's postulates were completed for all three diseases.
Pathogenicity of $P$. syringae pathovars. The broccoli raab and broccoli pathogens caused leaf blight symptoms on all crucifers tested, a leaf speck on tomato, and leaf lesions on several monocots: brome, oat, and common timothy (Table 2 ). Corn and rye plants remained asymptomatic. In contrast, $P$. syringae pv. maculicola strains caused leaf spot symptoms on all crucifers except broccoli raab, had variable reactions on tomato, and did not cause symptoms on any monocot host. $P$. syringae pv. tomato strains caused bacterial speck symptoms on tomato, but all other hosts remained asymptomatic. P. syringae pv. coronafaciens strains caused symptoms on oat, rye, and brome, but did not induce symptoms on any cruciferous host, corn, timothy, or tomato. The P. syringae pv. syringae strain did not cause symptoms on any host tested. None of the control plants inoculated with water and Tween 20 developed symptoms. Pathogenecity test results were consistent for all strains within a pathovar group, except for $P$. syringae pv. maculicola on tomato. In general, results from individual experiments were identical for all strains. However, variable reactions occurred on tomato with $P$. syringae pv. maculicola and the pathogen from broccolini (Table 2).

Phenotypic characterization of bacterial pathogens. LOPAT reactions confirmed that strains were $P$. syringae. All strains were positive for levan production, produced a hypersensitive response on tobacco, and were $\mathrm{KOH}$ positive, i.e., gram negative (Table 3 ). The strains were oxidase negative, arginine dihydrolase negative, and did not rot potato slices.

The broccoli raab and broccoli strains, Pseudomonas syringae $\mathrm{pv}$ syringae, and $P$. syringae pv. coronafaciens strains nucleated ice (Table 3 ). The broccolini strains,

Table 2. Disease response of new crucifer pathogens and pathovars of Pseudomonas syringae on crucifers, monocots, and tomato

\begin{tabular}{|c|c|c|c|c|c|c|c|c|}
\hline \multirow[b]{3}{*}{ Experimental host $^{x}$} & \multicolumn{8}{|c|}{ P. syringae ${ }^{\mathrm{v}}$} \\
\hline & \multicolumn{2}{|c|}{$\begin{array}{c}\text { P. syringae pv. alisalensis } \\
\text { Host }^{\text {w }} \\
\end{array}$} & \multirow{2}{*}{$\begin{array}{c}\text { P. syringae pv. } \\
\text { tomato }\end{array}$} & \multicolumn{2}{|c|}{$\begin{array}{c}\text { P. syringae pv. maculicola } \\
\text { Host }\end{array}$} & \multirow{2}{*}{$\begin{array}{l}\text { P. syringae pv. } \\
\text { coronafaciens }\end{array}$} & \multirow{2}{*}{$\begin{array}{l}\text { P. syringae } \\
\text { pv. syringae }\end{array}$} & \multirow[b]{2}{*}{ Negative controly } \\
\hline & Broccoli raab & Broccoli & & Broccolini & Various & & & \\
\hline Broccoli raab & $t^{\mathrm{z}}$ & + & - & - & - & - & - & - \\
\hline Broccoli & + & + & - & + & + & - & - & - \\
\hline Broccolini & + & + & - & + & + & - & - & - \\
\hline Cauliflower & + & + & - & + & + & - & - & - \\
\hline Tomato & + & + & + & $+1-$ & $+1-$ & - & - & - \\
\hline California brome & + & + & - & - & - & + & - & - \\
\hline Corn & - & - & - & - & - & - & - & - \\
\hline Oat & + & + & - & - & - & + & - & - \\
\hline Rye & - & - & - & - & - & + & - & - \\
\hline Timothy & + & + & - & - & - & - & - & - \\
\hline \multicolumn{9}{|c|}{ 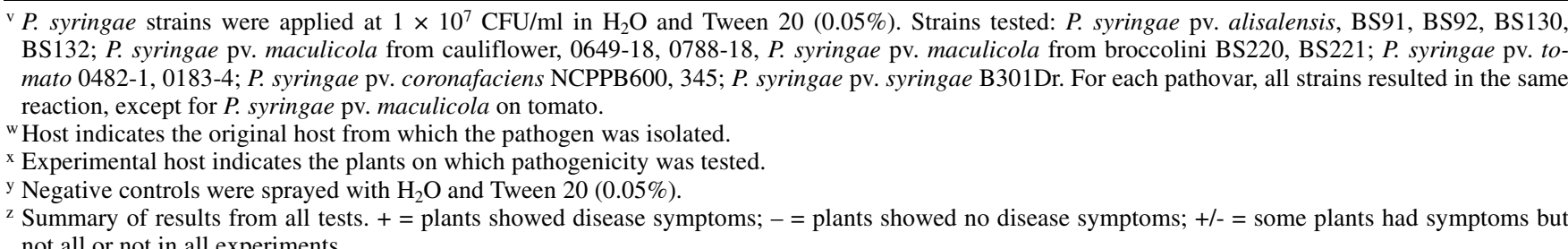 } \\
\hline
\end{tabular}


$P$ syringae pv. tomato, and $P$. syringae pv. maculicola did not nucleate ice.

The broccoli raab and broccoli strains were sensitive to the bacteriophage PBS1 (Table 3). P. syringae pv. coronofaciens, $P$. syringae pv. maculicola, $P$. syringae pv. tomato, and $P$. syringae pv. syringae were not sensitive to the phage.

Coronatine production genes were found to be present in all strains of all pathovars tested except for $P$. syringae pv. coronafaciens and $P$. syringae pv. syringae (Table $3)$.

Strains were compared by their carbon source utilization profiles on Biolog GN microplates (Biolog, Inc., Hayward, CA). All were identified as pathovars of Pseudomonas syringae. Fatty acid methyl esters (FAME) analysis identified strains as Pseudomonas syringae with a similarity index of 0.80 or higher.

Single carbon source tests differentiated the broccoli raab strains from all other strains tested (Table 3 ). The broccoli raab, broccoli, and $P$. syringae pv. coronafaciens strains were distinguished from other strains because they did not grow on trigonelline while the broccolini strains, $P$. syringae pv. tomato, $P$. syringae pv. syringae, and $P$. syringae pv. maculicola strains grew on trigonelline. Although $P$. syringae pv. coronafaciens does not grow on trigonelline, it grows on erythritol, which was not used by the broccoli raab and broccoli strains. Results from carbon utilization tests were identical for the broccolini strains, $P$. syringae pv. tomato, and P. syringae pv. maculicola.

Genetic characterization. Primers corresponding to $\mathrm{BOX} 1 \mathrm{~A}$ subunits of $\mathrm{BOX}$ elements annealed to genomic DNA and generated unique genomic fingerprints for each pathovar of $P$. syringae (Fig. 1). Fragments ranging in size from 0.6 to 3.0 kbp were amplified with the BOXA1R primer. Distinctive profiles were generated for all of the previously identified pathovars of $P$. syringae ( $P$. syringae pv. tomato, $P$. syringae pv. maculicola, $P$. syringae pv. coronafaciens, and $P$. syringae pv. syringae) evaluated. All strains tested within a given pathovar had the identical profiles with only minor polymorphisms occurring in some cases $(P$. syringae pv. coronafaciens and $P$. syringae pv. tomato). The profiles of the broccolini strains were identical to the $P$. syringae pv. maculicola strains evaluated.
The broccoli raab and broccoli strains had a unique profile.

\section{DISCUSSION}

Three new foliar bacterial diseases of crucifers, on broccoli raab, broccoli, and broccolini, have recently emerged in the Salinas Valley. Phenotypic characteristics as well as fatty acid and genetic tests indicate that these strains are LOPAT group I fluorescent pseudomonads (24) and are, therefore, $P$. syringae van Hall. Initial research on these diseases did not completely characterize the causal agents and their relationship(s) to each other $(5,6,20,21)$. We further characterized the pathogens and

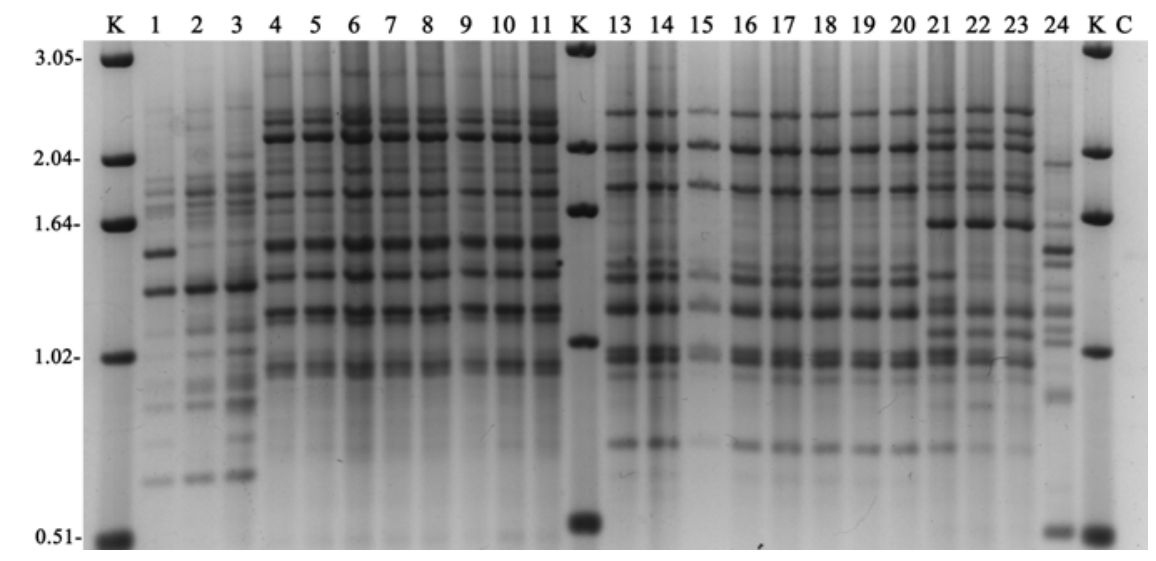

Fig. 1. Repetitive sequence-based polymerase chain reaction (BOX-PCR) fingerprints from Pseudomonas syringae pathovars with the BOX1AR primer. A portion of the PCR products $(9 \mathrm{ml})$ was loaded in a $1.5 \%$ agarose gel, and electrophoresis was performed at $70 \mathrm{~V}$ for $12 \mathrm{~h}$ in $0.5 \times$ TAE buffer $\mathrm{K}, 1 \mathrm{~kb}$ DNA Ladder; sizes are indicated in kilobase pairs. C, water control. Lanes 1 to 3 are $P$. syringae pv. coronofaciens. Lane 1, 345; 2, ICMP 3114; 3, NCPPB600. Lanes 4 to 11 are P. syringae pv. alisalensis. Lane 4, BS130; 5, BS132; 6, BS136; 7, BS91; 8, BS92; 9, BS101; 10, BS106; 11, BS228. Lanes 13 to 17 are $P$. syringae pv. maculicola.from broccolini. Lane 13, 220; 14, 221; 15, $235 ; 16,236 ; 17,244$. Lanes 18 to 20 are previously identified $P$. syringae pv. maculicola. Lane 18 , 788-18; 19, 0649-18; 20, 90-32-7A. Lanes 21 to 23 are P. syringae pv. tomato. Lane 21, 0482-1; 22, 0183-4, 23, 0683-23. Lane 24 is $P$. syringae pv. syringae, B301Dr.

Table 3. Characterization of Pseudomonas syringae strains

\begin{tabular}{|c|c|c|c|c|c|c|c|}
\hline \multirow[b]{4}{*}{ Test $^{\mathbf{y}}$} & \multicolumn{7}{|c|}{ P. syringae $^{\mathrm{w}}$} \\
\hline & \multirow{2}{*}{\multicolumn{2}{|c|}{$\begin{array}{c}\text { P. syringae pv. alisalensis } \\
\text { Host }^{\mathrm{w}}\end{array}$}} & \multirow{3}{*}{$\begin{array}{l}\text { P. syringae pv. to- } \\
\text { mato }\end{array}$} & \multirow{2}{*}{\multicolumn{2}{|c|}{$\begin{array}{c}\text { P. syringae pv. maculicola } \\
\text { Host }\end{array}$}} & \multirow{3}{*}{$\begin{array}{l}\text { P. syringae pv. } \\
\text { coronafaciens }\end{array}$} & \multirow{3}{*}{$\begin{array}{l}\text { P. syringae pv. } \\
\text { syringae }\end{array}$} \\
\hline & & & & & & & \\
\hline & Broccoli raab & Broccoli & & Broccolini & Various & & \\
\hline Levan production & $t^{z}$ & + & + & + & + & + & + \\
\hline Oxidase & - & - & - & - & - & - & - \\
\hline Potato & - & - & - & - & - & - & - \\
\hline Arginine & - & - & - & - & - & - & - \\
\hline Tobacco HR & + & + & + & + & + & + & + \\
\hline $\mathrm{KOH}$ reaction & + & + & + & + & + & + & + \\
\hline Ice nucleation & + & + & - & - & - & + & + \\
\hline Phage sensitivity & + & + & - & - & - & - & - \\
\hline Coronatine genes & + & + & + & + & + & - & - \\
\hline \multicolumn{8}{|l|}{ Carbon utilization } \\
\hline Tartaric acid & + & + & + & + & + & - & - \\
\hline Erythritol & - & - & - & - & - & + & + \\
\hline Trigonelline & - & - & + & + & + & - & + \\
\hline Ascorbic Acid & - & - & + & + & + & + & + \\
\hline
\end{tabular}


clarified the relationships among the causal agents of these three crucifer diseases. We demonstrated that a novel pathogen caused bacterial blights on both broccoli raab and broccoli and that this pathogen was distinct from $P$. syringae pv. maculicola causing bacterial leaf spot on broccolini.

Data suggested that a single unique pathogen caused bacterial blight of both broccoli raab and broccoli. This new pathogen is referred to as $P$. syringae pv. alisalensis in the rest of this manuscript. $P$. syringae pv. alisalensis infected all crucifers tested to date (21) including broccolini. Its ability to cause disease on crucifers suggested that it was similar to other coronatine producers such as $P$. syringae pv. maculicola and $P$. syringae pv. tomato. However, neither of these pathogens caused disease on broccoli raab. Interestingly, $P$. syringae pv. alisalensis infected grasses including California brome, oat, and common timothy, as well as crucifers. $P$. cichorri is the only other phytopathogenic pseudomonad known to cause disease on both crucifers and grasses. It was isolated from crucifers but caused disease on oat when artificially inoculated (3). Here we described the first pathovar of $P$. syringae with a host range that included both crucifers and monocots. This unique host range was sufficient to designate this organism as a new pathovar (9); however, additional genetic (BOX-PCR), phenotypic (ice nucleation and phage sensitivity), and biochemical (carbon source utilization) data further supported this designation.

Taxonomy and subsequent nomenclature of $P$. syringae and related pathogens has been in flux since the 1980 publication of the Approved Lists of Bacterial Names (35) when all plant pathogens that resembled $P$. syringae were lumped into this species regardless of host range. Plant pathologists used the infrasubspecific epithet pathovar to differentiate among plant pathogens with distinct host ranges. Research is currently being conducted to differentiate and designate independent species from pathovars of $P$. syringae. Distinct genomospecies can be distinguished using DNA-DNA hybridization techniques but these groups do not always coincide with species based on phenotypic tests (12). Because genetic data and phenotypic data do not yet concur, we followed the current convention and proposed that the new pathogen of broccoli raab is a pathovar of $P$. syringae. However, as soon as phenotypic characteristics can be correlated to the genetic data, this pathogen should be characterized and placed in its appropriate genomospecies. P. syringae pv. alisalensis may be a member of genomospecies 3 because it phenotypically resembled the genomotype $(P$. syringae pv. tomato) and an additional member of this genomospecies $(P$. syringae pv. maculicola $;$ 12).
P. syringae pv. maculicola is the most important pseudomonad causing disease on crucifers. $P$. syringae pv. maculicola (originally designated Bacterium maculicolum) was first described as a leaf spot pathogen from cauliflower in 1911 by McCulloch (29) and since that time it has been described on at least 25 members of the Brassicaceae including broccoli $(3,42)$. It is a common leaf spot pathogen of crucifers and is the causal agent of bacterial leaf spot on broccoli and cauliflower in the Salinas Valley (40). We correctly hypothesized that bacterial leaf spot on broccolini was caused by $P$. syringae pv. maculicola. Results from phenotypic, genetic, and host range tests were identical for the strains causing bacterial leaf spot on broccolini and reference $P$. syringae pv. maculicola strains. The recent emergence of this pathogen on broccolini may be because this is a relatively new crucifer commercialized in 1998 (H. Bouzar, personal communication).

P. syringae pv. maculicola and P. syringae pv. tomato are closely related (12) and some authors have suggested that these names are synonyms of one pathovar $(13,36)$. There may be overlap in the host range of these pathogens. For example, strains of $P$. syringae pv. tomato caused disease on cauliflower in some $(13,27,36)$ but not all studies (40). Our host range data supported the hypothesis that these are two separate but closely related pathovars $(27,40)$ because a clear difference in host range was obtained for reference strains of $P$. syringae pv. maculicola including the new strains from broccolini and $P$. syringae pv. tomato. P. syringae pv. tomato did not cause disease on broccoli, broccolini, or cauliflower while all $P$. syringae pv. maculicola strains caused disease. However, we used only a few well characterized strains in our studies. More variability might be seen in analysis of a greater number of strains. In contrast, reactions varied among reference strains of $P$. syringae pv. maculicola. Some caused severe necrotic flecking and chlorosis (BS 119, 0788-18) on tomato while others (BS121, 0649-18) resulted in both asymptomatic and light flecking reactions.

We have also seen differences in the reaction of $P$. syringae pv. alisalensis on tomato. In the experiments described here, which were conducted at two locations (USDA and UCCE), $P$. syringae pv. alisalensis was pathogenic on tomato. This result was inconsistent with data previously published from work done at the UCCE location (21). In the studies reported in this paper, the inoculum concentration was carefully adjusted for each experiment, and bacteria were applied as water suspensions. For the previous experiments, overnight nutrient broth cultures were used as inoculum without adjusting the population density (21). Because of the variability in pathogenicity tests on tomato, it was important to control as many parameters as possible within and among tests. We have conducted this experiment numerous times, controlling for as many factors as possible and are confident that the $P$. syringae pv. alisalensis is also a pathogen of tomato.

Host range data from strains of $P$. syringae pv. coronafaciens resulted in disease on some but not all of the known hosts for this pathovar. It caused disease when sprayed on oat, rye, and brome, but not on common timothy or corn. Corn and common timothy are natural hosts for some but not all strains of $P$. syringae pv. coronafaciens $(3,32)$. However, the $P$. syringae pv. coronafaciens strains tested did not cause disease on crucifers, which distinguishes them from the $P$. syringae pv. alisalensis strains. In addition, the presence of coronatine production genes in the $P$. syringae pv. alisalensis strains also distinguishes them from the $P$. syringae pv. coronafaciens strains, in which the coronatine production genes were not present.

Analysis of distances between repetitive extragenic sequences using rep-PCR protocols is a powerful tool for distinguishing related bacterial taxa. It has been used to successfully distinguish and identify bacterial plant pathogens both in situ and in vivo (31). Specifically, BOX-PCR (rep-PCR using the BOX repetitive extragenic sequences) is able to distinguish pathovars of $P$. syringae $(14,19,28,39,42)$. BOX-PCR banding patterns can be unique fingerprints that correspond to a single pathovar. Alternatively, several banding patterns may be generated by different strains of a single pathovar $(26,42)$. For example, Zhao et al. (42) used BOX-PCR to help assign the causal agent of bacterial spot on spinach (Spinacia oleracea), mustard (Brassica juncea), turnip (Brassica napus), and kale (Brassica oleracea var. acephala) to $P$. syringae pv. maculicola. This pathovar had two possible distinct profiles, A or B (42). This indicates that $P$. syringae pv. maculicola may have converged from at least two evolutionary lines. In this research, three strains used as positive controls for $P$. syringae pv. maculicola and five formerly uncharacterized $P$. syringae pv. maculicola strains from broccolini had identical banding patterns. The profiles from group B (42) appeared similar to the profile of the strains from broccolini. The broccolini strains were isolated in the Salinas Valley. The limited number of $P$. syringae pv. maculicola strains and the limited geographic distribution of pathogen origin probably resulted in our observation of only one group. However, it would be interesting to know if group A occurs in the Salinas Valley.

In addition to observing a unique fingerprint for the $P$. syringae pv. maculicola strains tested, unique fingerprints were obtained for $P$. syringae pv. tomato and $P$. syringae pv. coronafaciens. Although the 
$P$. syringae pv. tomato fingerprint was distinct, one strain had a slight polymorphism. In the research by Zhao et al. (42), two $P$. syringae pv. tomato strains, including the well characterized strain DC3000, had banding patterns corresponding to group A of $P$. syringae pv. maculicola. However, the banding patterns of three other strains of $P$. syringae pv. tomato were unique and appear to be similar to those presented in this study.

BOX-PCR successfully distinguished $P$. syringae pv. alisalensis from $P$. syringae pv. maculicola, $P$. syringae pv. tomato, and $P$. syringae pv. coronafaciens. These data supported the hypothesis that the $P$. syringae pv. alisalensis is a new pathovar of $P$. syringae. The ability of rep-PCR to distinguish this pathovar from other $P$. syringae pathovars may be useful for rapid identification from field infections.

To date, $P$. syringae pv. maculicola was found on broccolini from only one commercial transplant greenhouse. This disease has not been found on broccolini in the field. However, P. syringae pv. maculicola is a pathogen of many crops grown in rotation with broccolini in the Salinas Valley including cauliflower and broccoli (40). $P$. syringae pv. alisalensis has a broader host range infecting many crucifers as well as grasses. Since 1995, we have found this pathogen each year in broccoli raab plantings. This pathogen was also found in the same commercial broccoli field in two consecutive years. In the Salinas Valley, crucifers can be planted back-to-back with as little as a week between incorporation of previous crop and planting of the subsequent crop. Residue from infected crops is a significant inoculum source for up to 4 months after incorporation (7). Rotation with crops, for which soils are fumigated annually, is currently used to control soilborne diseases in vegetable production fields. The fumigant methyl bromide will no longer be available after 2005, and diseases like the ones described here may become more important if fumigation is no longer used. Considering the tight cropping sequence and overlap in the host range of the two pathogens characterized here, tools for rapid identification would be useful in making recommendations for rotation crops. For example, if a bacterial disease occurs on broccoli, rapid identification of $P$. syringae pv. maculicola would suggest that a grower could grow broccoli raab or a cover crop with grasses without risk of disease developing from the same pathogen. In contrast, this would not be true if the pathogen was identified as $P$. syringae pv. alisalensis. This research provided the initial information needed to develop rapid identification methods using BOX-PCR and significant host range data for two pathogens found in this region.

Description of $P$. syringae pv. alisalensis pv. nov. The bacterium formed colonies that were circular, entire, and convex and had one to five polar flagella (21). Strains glistened on MGY plates and fluoresced with a bluish green pigment on KMB. All strains were gram negative. In LOPAT tests, strains were positive for levan production and tobacco hypersensitivity, but negative for oxidase, arginine dihydrolase, and ability to rot potato, identifying the organism as $P$. syringae. Strains did not reduce nitrate nor liquefy gelatine and were variable for urease activity (21). Mannitol, inositol, sorbitol, glycerol, glucose, sucrose, arabinose, mannose, D (-), tartrate, citrate, succinate, malonate, L (-), L (+), and DL-tartrate, and DL-lactate were utilized as carbon sources. Strains were not able to utilize erythritol, trigonelline, D (+) tartrate, meso-tartrate, molybdate, acetate, propionate, maleate, rhamnose, and L (+) lactate. Utilization of $\mathrm{L}(-)$ lactate and growth on MacConkey agar were weakly positive (21). The strains produced ice nuclei and were sensitive to phage PBS1. All of the strains had DNA to which the coronatine production genes from DC3000 hybridized. None of the strains induced pitting on polypectate gel (21). Hosts were the following: Natural hosts-broccoli raab and broccoli; Artificial inoculationbroccolini, cauliflower, arugula (Eruca sativa), bok choy (Brassica campestris subsp. chinensis), cabbage (Brassica oleracea subsp. capitata), Chinese cabbage (Brassica campestris subsp. pekinensis), Japanese mustard (Brassica campestris subsp. nipposinica), red mustard (Brassica juncea subsp. rugosa), and tah tsai (Brassica campestris subsp. nari-nosa) tomato, California brome, oat, and common timothy. Corn and rye were not hosts.

\section{ACKNOWLEDGMENTS}

Special thanks to Diana Henderson, Thi Duong, E. J. Rowland, and Rose Vega for technical support on this project; R. Bunch, $\mathrm{H}$. Bouzar, and $\mathrm{H}$. Azad for strains, seed, and discussion; and E. Little and J. Barak who reviewed the manuscript prior to submission.

\section{LITERATURE CITED}

1. Anonymous 2002. Vegetables and Melons Outlook. USDA, Economic Research Service, Bull. VGS-289.

2. Ausubel, F. M., Brent, R., Kingston, R. E., Moore, D. D., Seidman, J. G., Smith, J. A., Struhl, K. 1987. Current Protocols in Molecular Biology. Wiley-Interscience, New York.

3. Bradbury, J. F. 1986. Guide to Plant Pathogenic Bacteria. CAB International, Slough, UK.

4. Canteros de Echenique, B. I., Zagory, D., Stall, R. E. 1985. A medium for cultivation of the B-strain of Xanthomonas campestris pv. citri, cause of cancrosis B in Argentina and Uruguay. Plant Dis. 69:122-123.

5. Cintas, N. A., Bull, C. T., Koike, S. T., and Bouzar, H. 2001. A new bacterial leaf spot disease of broccolini, caused by Pseudomonas syringae pathovar maculicola, in California. Plant Dis. 85:1207.

6. Cintas, N. A., Koike, S. T., Bull, C. T. 2001. Emerging bacterial pathogens of crucifers in the Salinas Valley of California, Pages 272274 in: Plant Pathogenic Bacteria, S. H. DeBoer, ed. Kluwer Academic Publishers, Boston, MA.
7. Cintas, N. A., Koike, S. T., and Bull, C. T. 2000. Rappini bacterial blight declines with delayed replanting in the Salinas Valley of California. Phytopathology 90:S15.

8. Cupples, D. A., Moore, R. A., Morris, V. L. 1990. Construction and use of a nonradioactive DNA hybridization probe for detection of Pseudomonas syringae pv. tomato on tomato plants. Appl. Environ. Microbiol. 56:17431749.

9. Dye, D. W., Bradbury, J. F., Goto, M., Hayward, A. C., Lelliot, R. A., Schroth, M. N. 1980. International standards for naming pathovars of phytopathogenic bacteria and a list of pathovar names and pathotype strains. Rev. Plant Pathol. 59:153-168.

10. Fahy, P. C., and Hayward, A. C. 1983. Media and methods for isolation and diagnostic tests. Pages 337-378 in: Plant Bacterial Diseases. P. C. Fahy, and G. J. Persley, eds. Academic Press, NY.

11. Fanizza, G., Damato, G., and Bianco, V. V. 1992. A multivariate morphometric study on landrace differentiation in broccoli raab (Brassica rapa L.). Acta Hortic. 318:195-200.

12. Gardan, L., Shafik, H., Belouin, S., Broch, R. Grimont, F., and Grimont, P. A. D. 1999. DNA relatedness among the pathovars of Pseudomonas syringae and description of Pseudomonas tremae sp. nov. and Pseudomonas cannabina sp. nov. (ex Sutic and Dowson 1959). Int. J. Syst. Bacteriol. 49:469-478.

13. Hendson, M., Hildebrand, D. C., and Schroth, N. 1992. Relatedness of Pseudomonas syringae pv. tomato, Pseudomonas syringae pv. maculicola, and Pseudomonas syringae pv. antirrhini. J. Appl. Bacteriol. 73:455-464.

14. Hollaway, G. J., Bretag, T. W. 1997. Survival of Pseudomonas syringae pv. pisi in soil and on pea trash and their importance as a source of inoculum for a following field pea crop. Aust. J. Exp. Agric. 37:369-375.

15. Keane, P. J., Kerr, A., and New, P. B. 1970 Crown gall of stone fruit. II. Identification and nomenclature of Agrobacterium isolates. Aust. J. Biol. Sci. 23:585-595.

16. King, E. O., Ward, M. K., and Raney, D. E. 1954. Two simple media for the demonstration of pyocyanin and fluorescin. J. Lab. Clin. Med. 44:301-307.

17. Klement, Z., Rudolf, K., Sands, D. C. 1990. Methods in Phytobacteriology. Akadémiai Kiadó, Budapest.

18. Koike, S. T. 1997. Broccoli raab as a host of Alternaria brassicae in California. Plant Dis. 81:552.

19. Koike, S. T., Barak, J. D., Henderson, D. M. and Gilbertson, R. L. 1999. Bacterial blight of leek: a new disease in California caused by Pseudomonas syringae. Plant Dis. 83:165170.

20. Koike, S. T., Cintas, N. A., and Bull, C. T. 2000. Bacterial blight, a new disease of broccoli, caused by Pseudomonas syringae, in California. Plant Dis. 84:370.

21. Koike, S. T., Henderson, D. M. Azad, H. R., Cooksey, D. A., and Little, E. L. 1998. Bacterial blight of broccoli raab: a new disease caused by a pathovar of Pseudomonas syringae. Plant Dis. 82:727-731.

22. Koike, S. T., and Saenz, G. S. 1997. First report of powdery mildew, caused by Erysiphe cruciferarum, on broccoli raab in California. Plant Dis. 81:1093.

23. Lauritzen, E. 2000. Monterey County Agricultural Commissioner 1998 Crop Report, CA.

24. Lelliott, R. A., Billing, E., and Hayward, A. C. 1996. A determinative scheme for the fluorescent plant pathogenic Pseudomonads. J. Appl. Bacteriol. 29:470-489.

25. LeStrange, M., Mayberry, K. S., Koike, S. T., and Valencia, J. 1996. Broccoli production in 
California. University of California. Division of Agriculture and Natural Resources. Publication 7211 .

26. Little, E. L., Bostock, R. M., Kirkpatrick, B. C. 1998. Genetic characterization of Pseudomonas syringae pv. syringae strains from stone fruits in California. Appl. Environ. Microbiol. 64: 3818-3823.

27. Little, E. L., Gilbertson, R. L. 1997. Phenotypic and genotypic characters support placement of Pseudomonas syringae strains from tomato, celery, and cauliflower into distinct pathovars. Pages 542-547 in: Pseudomonas syringae Pathovars and Related Pathogens. K. Rudolf, T. J.Burr, J. W.Mansfield, D. Stead, A. Vivian, J. von Kietzell, eds. Kluwer Academic Publishers, Boston, MA.

28. Louws, F. J., Fulbright, D. W., Stephens, C. T., and De Bruijn, F. J. 1994. Specific genomic fingerprints of phytopathogenic Xanthomonas and Pseudomonas pathovars and strains generated with repetitive sequences and PCR. Appl. Environ. Microbiol. 60:2286-2295.

29. McCulloch, L. 1911. A spot disease of cauliflower, USDA, Bur. Plant Ind. Bull. 225:1-15.

30. Paisley, R. 1995. Page M-5 in: MIS Whole Cell Fatty Acid Analysis by Gas Chromatography. MIDI, Inc., Newark, DE.

31. Rademaker, J. L. W., Louws, F. J., and De
Bruijn, F. J. 1998. Characterization of the diversity of ecologically important microbes by rep-PCR genomic fingerprinting. Mol. Microbiol. Ecol. Man. 3.4.3:1-27.

32. Ribeiro, R. de L. D., Durbin, R. D., Arny, D. C., and Uchytil, T. F. 1977. Characterization of the bacterium inciting chocolate spot of corn. Phytopathology 67:1427-1431.

33. Sambrook, J., Fritsch, E. F., and Maniatis, T. 1989. Molecular cloning: a laboratory manual, 2nd ed. Cold Spring Harbor Laboratory Press, Cold Spring Harbor, N.Y.

34. Schaad, N. W., 1988. Laboratory Guide for Identification of Plant Pathogenic Bacteria. 2nd ed. American Phytopathological Society, St. Paul, MN.

35. Skerman, V. B. D., McGowan, V., and Sneath, P. H. A., eds. 1989. Approved lists of bacterial names. American Society for Microbiology, Washington, DC.

36. Takikawa, Y., Nishiyama, N., Ohba, K., Tsuyumu, S., and Goto, M. 1994. Synonymy of Pseudomonas syringae pv. maculicola and Pseudomonas syringae pv. tomato. Pages 199-204 in: Plant Pathogenic Bacteria, 8th International Conference on Plant Pathogenic Bacteria M. Lemattre, S. Freigoun, K. Rudolph, J. G. Swings eds. Les Colloques Editions, INRA, Paris, France.
37. Verhoeven D. T., Verhagen, H., Goldbohm, R. A., van den Brandt, P. A., van Poppel, G 1997. A review of mechanisms underlying anticarcinogenicity by brassica vegetables. Chem. Biol. Interact. 103:79-129.

38. Versalovic, J., Schneider, M., De Bruijn, F. J., and Lupski, J. R. 1994. Genomic fingerprinting of bacteria using repetitive sequencebased polymerase chain reaction. Methods Mol. Cell. Biol. 5:25-40.

39. Weingart, H., and Völksch, B. 1997. Genetic fingerprinting of Pseudomonas syringae pathovars using ERIC-, REP-, and IS50-PCR. J. Phytopathol. 145:339-345.

40. Wiebe, W. L., and Campbell, R. N. 1993. Characterization of Pseudomonas syringae pv. maculicola and comparison with $P$. s . tomato. Plant Dis. 77:414-419.

41. Xu, G.-W., and Gross, D. C. 1988. Evaluation of the role of syringomycin in plant pathogenesis by using Tn5 mutants of Pseudomonas syringae pv. syringae defective in syringomycin production. Appl. Environ. Microbiol. 54:1345-1353.

42. Zhao, Y. F., Damicone, J. P., Demezas, D. H., Rangaswamy, V., Bender, C. L. 2000. Bacterial leaf spot of leafy crucifers in Oklahoma caused by Pseudomonas syringae pv. maculicola. Plant Dis. 84:1015-1020. 